\title{
津波漂流物の捕捉機能を有する植栽の 設計に関する研究 \\ RESEARCH ON THE DESIGN OF PLANTING \\ WITH THE CAPTURE FUNCTION OF FLOATING OBJECTS DURING TSUNAMI
}

\author{
林晃大 $^{1} \cdot$ 今井健太郎 ${ }^{2} \cdot$ 今村文彦 $^{3}$ \\ Akihiro HAYASHI, Kentaro IMAI and Fumihiko IMAMURA \\ 1 学生会員 東北大学大学院工学研究科博士前期課程 ( T 980-8579 仙台市青葉区荒巻字青葉 6-6-11-1106) \\ 2 正会員 博 (工) 東北大学助教 災害科学国際研究所 (同上) \\ 3 正会員 工博 東北大学教授 災害科学国際研究所 (同上)
}

\begin{abstract}
Trapping mechanism of floating objects during tsunami due to aligned trees was investigated through field surveys and hydraulic experiments. From the hydraulic experiment, the physical factors related to roadside trees and explaining the capture of floating objects were obtained. In addition, we show the maximum momentum limit at which trees fall when floating objects were trapped. Using the floating objects capture evaluation method of the trees that considered falling of trees, a verification case was performed knowing the specifications of the trees and floating objects in Tagajo city in case of the 2011 Tohoku earthquake and tsunami. We proved that the trees in Tagajo city did not fall even if it trapped floating objects during tsunami, generally agreeing on the quantity of the trapping ratio.
\end{abstract}

Key Words: $\quad$ floating objects, trees, hydraulic experiments, momentum, trapping ratio

1.はじめに

2011 年 3 月 11 日に発生した東北地方太平洋沖地震 による津波は, 東北地方の沿岸地域に壞滅的な被害を もたらした . 林野庁 ${ }^{1)}$ の発表によると，今回の津波に よる青森, 岩手, 宮城, 福島, 茨城, 千葉の 6 県の海 岸林の浸水被害は約 3660 ha であり，空中写真等を用い て流失・水没・倒伏状況を判読した結果，被害区分 75 \%以上か約 3 割, 25〜75\%か約 2 割強と, かつてない 甚大な被害状況となった。

既往研究によると, 首藤 ${ }^{2)}$ (過去の津波事例から防 潮林による津波被害軽減効果についての評価を試み，防 潮林の津波流勢の低減や船舶などの津波漂流物捕捉，津 波にさらわれた人がすがりつく対象物としての緊急避 難施設としての機能を事例に基づいて示した .

樹木群による津波減勢効果 ${ }^{344)}$ ，樹木の倒伏耐力に関 する検討 5)677) についても，既往の研究成果により，実 用に耐えうる評価が可能となりつつある .一方で, 津 波漂流物の捕捉機能については，いずれの研究におい ても，これまでの事例に基づいた定性的議論 ${ }^{2) 8)} に と$ どまっている .

今井ら ${ }^{9)}$ (街路樹などの並木による漂流物捕捉機能 に関して, 現地調査や水理実験を通じて詳細な検討を 行い, 並木の漂流物捕捉機能について，並木と漂流物 の関係を定量的に示した . しかしながら，漂流物捕捉 に伴う倒伏などの樹木の物理的限界については検討さ れていない. 並木による漂流物捕捉機能を考慮した防
災施設を設計する上では, 倒伏などの限界を議論する ことは不可欠であると考えられる .

本研究では, 水理実験から得られた並木による津波 漂流物捕捉効果の定量的な知見に基ついて, 漂流物捕 捉時の並木の倒伏限界について検討するとともに事例 検証を行い，防災施設としての並木の適用性を明らか にすることを目的とする .

\section{2. 並木の津波漂流物捕捉機能}

(1) 今井ら (2012) の検討

図-1 は宮城県多賀城市において確認された並木によ る漂流物捕捉事例である. 敷地周りの並木により資材 及び車の敷地外への流失を阻止している樣子がわかる． 今井ら ${ }^{9)}$ は現地調査と水理実験の結果から，並木の津 波漂流物捕捉機能について定量的な評価手法を提案し た。評価に用いた変数は, 水理実験の結果から得られ た並木の津波漂流物捕捉機能に関わる物理因子である 津波漂流物の代表長さ (最大長) と並木間隔の比, 津 波外力，津波漂流物のアスペクト比と並木列数である 並木列数をより一般的な変数として表現するために植 生厚み $\left.d_{C} \cdot n^{2}\right)$ を用い $\left(d_{C}\right.$ は幹直径 $(\mathrm{m}), n$ は単位林 帯幅あたりの立木本数)，津波外力としては津波浸水深 $D$ と $d_{C}$ の比である $D / d_{C}$, 津波漂流物の代表長さ (最 大長) と並木間隔の比 $L_{m} / l_{t}\left(L_{m}\right.$ : 漂流物の代表長さ， $l_{t}$ : 並木間隔)，津波漂流物のアスペクト比 $L / W$ とし た . 漂流物捕捉割合 $R_{C}=N_{C} / N_{A}\left(N_{C}\right.$ : 並木により捕捉 


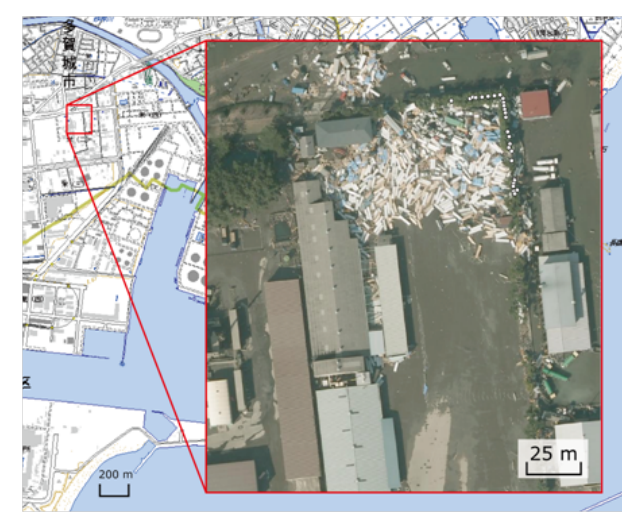

図-1 津波漂流物捕捉状況 (宮城県多賀城市の事例)

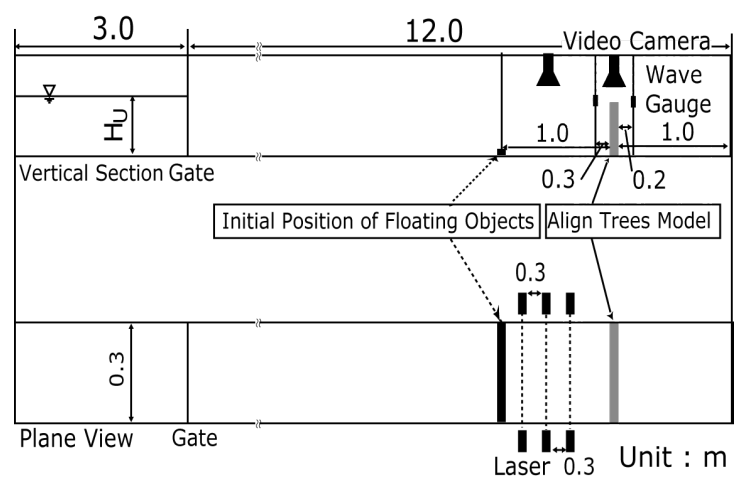

図-2 実験水路概要 (レーザー設置後)

された漂流物数, $N_{A}$ : 全漂流物数) を定義し， $R_{C}$ を実 験による評価の対象とした . 以下に关の関数型を示す。

$$
R_{\mathrm{c} 1}=\frac{1}{1+e^{-\Phi_{1}}}
$$

$$
\begin{aligned}
\Phi_{1}= & -0.31\left(d_{c} n\right)^{-0.34}\left(L_{m} / l_{t}\right)^{-0.93}\left(D / d_{c}\right)^{0.70}(L / W)^{0.40} \\
& +5.0 \pm \sigma
\end{aligned}
$$

ここで, $\sigma=0.93$, 決定係数 $R^{2}=0.8$, 有意水準 $p<0.001$ である．また，本式の適用範囲としては $d_{C} \cdot n<0.3$ ， $D / d_{C}<8,0.3<L_{m} / l_{t}<2.25, L / W<3$ である. 式 (1)，(2) により想定される並木の諸元と漂流物の種類を 選択することで，並木の津波漂流物捕捉機能を容易に 評価することが可能である .

\section{(2) 漂流物群条件についての水理実験}

a) 漂流物の群体規模の变化に伴う並木の津波漂流物捕 捉割合の変化

今井ら ${ }^{9)}$ の検討は，屋敷林に囲まれた資材場におけ る漂流物捕捉など，限定的な条件下での検討であった ため, 流下漂流物の規模については検討していない，し かしながら，実際の流下漂流物規模は漂流物の大きさ や数などの条件の問題による不確定要素が大きく，定 量把握は難しい，光こで, 漂流物の群体規模を変化さ せた場合の並木による津波漂流物捕捉機能を検討する ための水理実験を実施した .

図-2 に実験装置の概略を示す. 実験装置は全長 $15 \mathrm{~m}$ の断面一次元水槽を用いた . 表-1 に実験条件を示す.漂

\begin{tabular}{|c|c|}
\multicolumn{2}{c|}{ 表-1 実験条件 } \\
\hline 貯留水深 $\left(H_{U}\right)$ & $10,12,14 \mathrm{~cm}$ \\
\hline 漂流物 & 立方体 $(1.5 \mathrm{~cm} \times 1.5 \mathrm{~cm} \times 1.5 \mathrm{~cm})$ \\
\cline { 2 - 3 } 種類 & 直方体 $(4.5 \mathrm{~cm} \times 1.5 \mathrm{~cm} \times 1.5 \mathrm{~cm})$ \\
\hline 漂流物 & 立方体 $; 12,21,33,45,54,66,78,87,99$ \\
\cline { 2 - 2 } 個数 & 直方体; $4,7,11,15,18,22,26,29,33$ \\
\hline 漂流物初期位置 & $1 \mathrm{~m}$ \\
\hline 並木模型直径 & $0.4 \mathrm{~cm}$ \\
\hline 並木模型間隔 & $3 \mathrm{~cm}$ \\
\hline 並木模型列数 & 1 \\
\hline
\end{tabular}
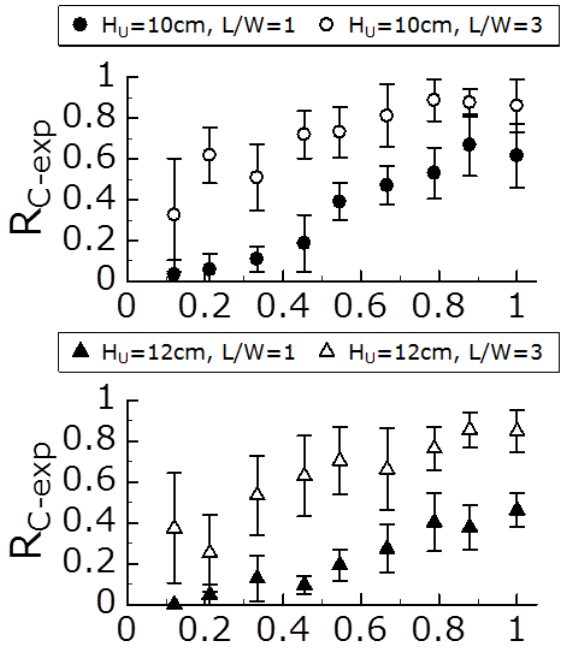

- $\mathrm{H}_{\mathrm{U}}=14 \mathrm{~cm}, \mathrm{~L} / \mathrm{W}=1 \quad \square \quad \mathrm{H}_{\mathrm{U}}=14 \mathrm{~cm}, \mathrm{~L} / \mathrm{W}=3$

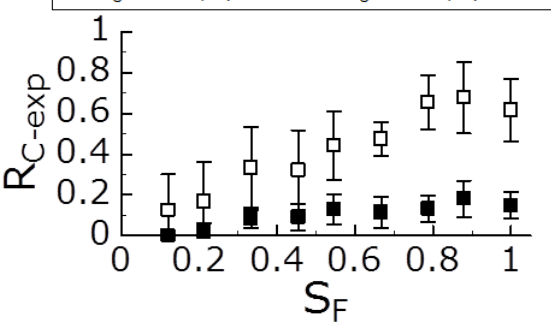

図-3 $S_{F}$ と津波漂流物捕捉割合の関係

流物模型は今井ら 9) の検討を参考に工業製品，車を想 定している. 並木模型は列数を増やすと漂流物捕捉能 力が向上する ${ }^{9)}$ が , 本検討では安全側の評価となるよ う 1 列のみの検討とした . 津波氾濫流はゲート急開流 れで模擬した . 氾濫流の相似則はフルード則を用い, 縮 尺は $1 / 100$ とした . 漂流物や樹木模型は縮尺のみ考慮 しており，樹木の弾性相似則 ${ }^{10)}$ は考慮していない . 樹 木模型は直径 $4 \mathrm{~mm}$ のステンレス円柱を用い, 並木の 配置条件は現地調査結果や実際の街路樹を参考にした。 実際には樹冠部の影響による漂流物捕捉効果も考えら れるが，より安全側の評価となるように，樹木模型と しては幹部のみとした . 貯留水深 $H_{U}=10,12,14 \mathrm{~cm}$ に おける，漂流物が存在しない場合の平均最大水位は光

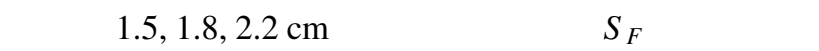
立方体 99 個，直方体 33 個の場合を基準とした比を示 す. 各実験条件に対して 10 回反復して実験を行い，再 現性の確認を行った .

計測項目は並木模型前面位置と背後部で超音波变位 計（キーエンス社製 UD-500，UD-020）により段波水 


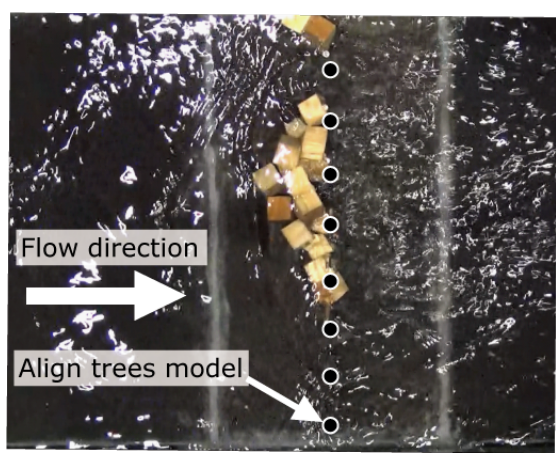

図-4 漂流物捕捉時の樣子

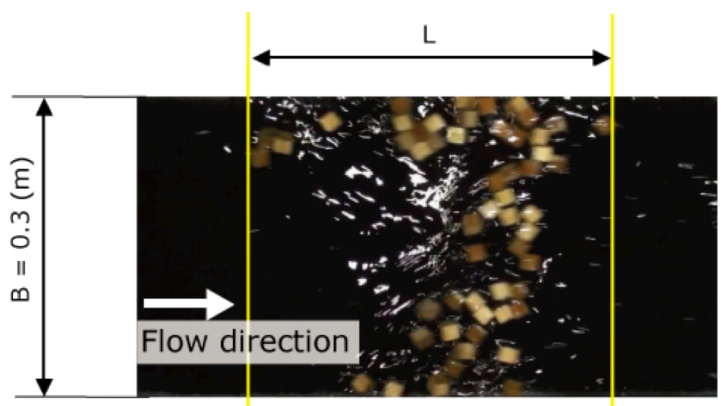

図-5 漂流物群密度の捉え方

位の経時変化を測定した．漂流物捕捉割合 $R_{C}{ }^{9)}$ を定義 し，実験による評価の対象とした .ただし，水槽側壁の 影響で捕捉された漂流物については評価から除外した .

図-3 に津波漂流物群の群体規模の变化に伴う漂流物 捕捉割合の変化を示す. 図から津波漂流物群の量か増 えるに従い，並木に捕捉される津波漂流物の割合が増 加する傾向にあることがわかる . 津波漂流物群の規模 が大きい場合は，津波漂流物群が流下時に群体を形成 することで, 並木に捕捉される際にアーチング ${ }^{11)}$ を形 成する (図-4) . 並木に捕捉された漂流物群によるアー チングの形成により，漂流物群を捕捉した並木列から の抗力と津波外力がつりあい, 捕捉量か増加する傾向 にある. 弚れに対して，津波漂流物群の規模が小さい 場合には，津波漂流物の振る舞いは単体のものに近く なり，アーチングの形成が難しくなるため，捕捉割合 は低い，また，津波外力に着目すると，漂流物の $L / W$ に関わらず，津波外力が強くなるほど捕捉割合の值は 低下し，たとえ漂流物群が並木に捕捉されて安定して いる状態 (図-4) でも, 流勢か強くなるとアーチングを 形成することができずに押し出される．

b) 流下漂流物の群密度. 移動速度と漂流物捕捉割合の 関連性

流下漂流物群の挙動を定量的に把握するべく，新た に漂流物群密度 $D_{f g}=\Sigma s /(B \cdot L)(\Sigma s:$ 漂流物群投影 面積, $B:$ 水路幅, $L:$ 漂流物群の流れ方向の拡散長さ) を定義した (図-5)． $D_{f g}$ は実際は単位面積あたりの 漂流物群密度を示し, 值が小さいほど流下漂流物群が 散けていることを意味する．漂流物群の流れ方向の拡 散長さ $L$ は水路側部にタッチセンサー (Panasonic 社製 EX-L200) を設置して (図-2)，漂流物群の通過時間及
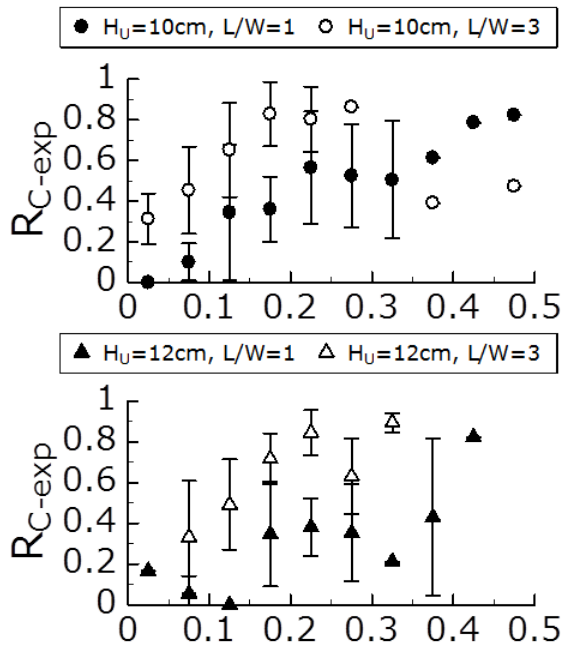

$H_{U}=14 \mathrm{~cm}, L / W=1 \quad \square H_{U}=14 \mathrm{~cm}, L / W=3$

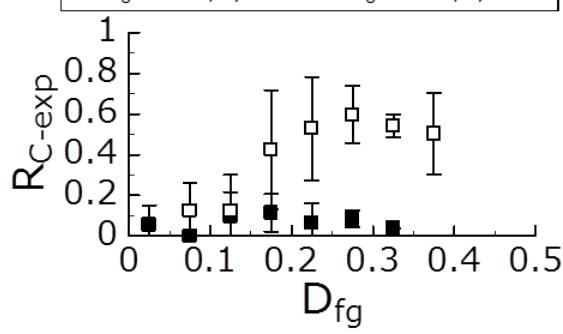

図-6 $D_{f g}$ と津波漂流物捕捉割合の関係

び移動速度から評価した。

図-6に $D_{f g}$ と津波漂流物捕捉割合の関係を示す . 実験 值 $R_{C-\exp }$ について, $D_{f g}$ の值が 0.05 毎の区間で光れ光 れの平均値を示した .いずれの場合もばらつきはあるも のの, おおよ光 $D_{f g}$ が大きくなると漂流物捕捉割合も大 きくなる傾向があり. 特に $L / W=1$ の $H_{U}=10,12 \mathrm{~cm}$ の場合について確認できる . 漂流物が群体を形成した 場合, 弚の大きさが並木間隔よりも大きくなり, 並木に 捕捉されやすくなることがいえる. $L / W=3$ において は, $D_{f g}$ が $0.1 \sim 0.2$ と比較的小さい值であっても，漂流 物捕捉割合が大きな值を示している例も確認できるが， 本実験条件においては $L / W=3$ のときは漂流物単体の 大きさが並木の間隔よりも大きく，比較的並木に捕捉 されやすい. $L / W=1$ の $H_{U}=14 \mathrm{~cm}$ の場合は, $D_{f g}$ の 值に関わらず漂流物捕捉割合は小さく, 津波外力の影 響が考えられる。

図-7 にフルード数 $F_{r}$ と津波漂流物捕捉割合の関係を 示す . 氾濫流速は, 漂流物群の移動速度と同程度と仮 定した . 全体的な傾向として, $F_{r}$ の増加にともなって 漂流物捕捉割合は減少していることが確認できる．流 速が大きい場合, 図-4 の状態のように漂流物群が並木 に捕捉された場合でも，流勢の強さによって押し出さ れることが実験でも確認されている．また， $L / W=3$ においては, $F_{r}$ が大きい值であっても漂流物捕捉割合 が大きな值を示している例も確認できる . 本実験条件 においては $L / W=3$ のときは漂流物単体の大きさが並 木の間隔よりも大きいため，比較的並木に捕捉されや すい. 

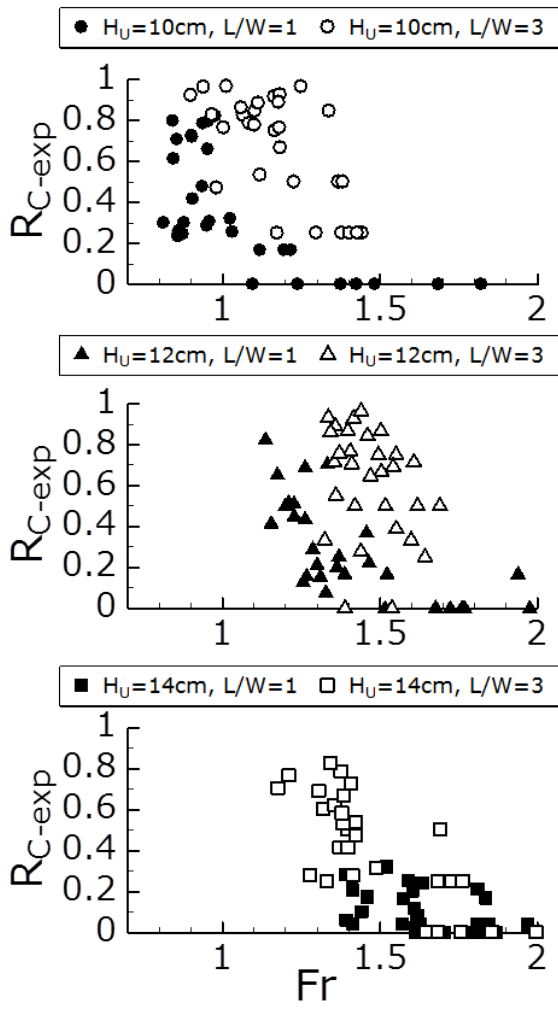

図-7 $F_{r}$ と津波漂流物捕捉割合の関係

表-2 各パラメータの偏相関係数

\begin{tabular}{|c|c|c|c|c|c|}
\hline Multi.Corr.Coef & $R_{C}$ & $D / d_{C}$ & $L / W$ & $D_{f g}$ & $F_{r}$ \\
\hline$R_{C}$ & 1.00 & & & & \\
\hline$D / d_{C}$ & 0.04 & 1.00 & & & \\
\hline$L / W$ & 0.67 & -0.02 & 1.00 & & \\
\hline$D_{f g}$ & 0.23 & 0.59 & -0.23 & 1.00 & \\
\hline$F_{r}$ & -0.44 & 0.55 & 0.34 & -0.38 & 1.00 \\
\hline
\end{tabular}

表-3 各評価式の c-AIC および決定係数 $R^{2}$

\begin{tabular}{|c|c|c|c|}
\hline Model & 使用パラメータ & $R^{2}$ & c-AIC \\
\hline$\Phi_{2_{1}}$ & $L / W, D / d_{C}, D_{f g}, F_{r}$ & 0.79 & -48.8 \\
\hline$\Phi_{2_{2}}$ & $L / W, D / d_{C}, F_{r}$ & 0.66 & -66.8 \\
\hline$\Phi_{2_{3}}$ & $L / W, D / d_{C}, D_{f g}$ & 0.80 & -19.8 \\
\hline$\Phi_{2_{4}}$ & $L / W, D_{f g}, F_{r}$ & 0.77 & -66.9 \\
\hline
\end{tabular}

以上から，流下漂流物群条件を考慮した漂流物捕捉 機能に関わりうる影響因子としては, $D_{f g}$, 津波外力， $L / W, F_{r}$ であることがわかる.

c) 漂流物群条件を考慮した並木の漂流物捕捉機能に関 する定量評価手法

水理実験により推定された各無次元パラメータを用 いて評価手法を構築していく.各パラメータの偏相関係 数から (表-2) , $R_{C 2}$ に有意な相関がみられるパラメー タとしては, $L / W$ と $D_{f g}$ であること, $F_{r}$ は $R_{C 2}$ と逆相 関にあることがわかる . また,$D / d_{C}$ と $D_{f g}, D / d_{C}$ と $F_{r}$ にも正の相関関係にあることがわかる . 以上から, 評価式に用いる説明変数としてのパラメータは, $L / W$ と $D / d_{C}, D_{f g}, F_{r}$ の3つのうちから 2 つ上上選択する

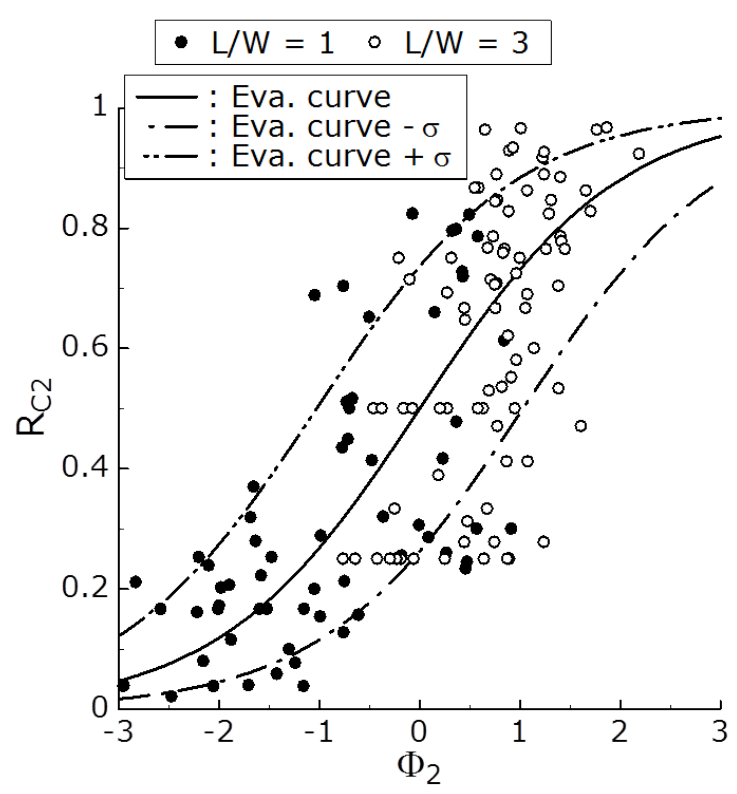

図-8 実験值と評価式 (3) の整合性

ことが適切と考えられる．水理実験の結果と統計学的 検討から， $L / W, D / d_{C}, D_{f g}, F_{r}$ の無次元パラメータ を，流下漂流物群条件を考慮した漂流物捕捉に関わる 説明変数として，標準シグモイド関数に基づいた評価 式を構筑した . 式 (3) に光の関数型を示す.

$$
R_{\mathrm{c} 2}=\frac{1}{1+e^{-\Phi_{2_{i}}}}
$$

ここで， $R_{C 2}$ は流下漂流物群条件を考慮した漂流物捕 捉割合である。また， $\Phi_{2_{1}}=f\left(L / W, D / d_{C}, D_{f g}, F_{r}\right)$, $\Phi_{2_{2}}=f\left(L / W, D / d_{C}, F_{r}\right), \Phi_{2_{3}}=f\left(L / W, D / d_{C}, D_{f g}\right), \Phi$ $2_{4}=f\left(L / W, D_{f g}, F_{r}\right)$ である. $\Phi$ はべキ関数型をとると した . 各変数における係数は実験值に基づいて最小二 乗法により決定した . 加えて, c-AIC ${ }^{12)}$ が最小かつ決 定係数 $R^{2}$ が最大の值となるような $\Phi$ を選んだ . 表-3 に $\Phi_{2_{1}} \sim \Phi_{2_{4}}$ の $R^{2}$, c-AIC の値を示す. 本実験範囲に おける最適なモデルは $\Phi_{2_{4}}$ であり，式 (4) に示す .

$$
\Phi_{2}=-4.2(L / W)^{-0.37} D_{f g}^{-0.11} F_{r}^{0.74}+5.0 \pm \sigma
$$

ここで, $\sigma=1.03, R^{2}=0.77$, 有意水準 $p<0.001$ である. 本式の適用範囲は $L / W<3,0<D_{f g} \leq 0.5,0.8<F_{r}$ < 2.0 である. 図-8 に実験值と評価式による計算值の 整合性を示す.式(3)，(4) より多少のばらつきがあるも のの本検討の範囲内において並木の漂流物捕捉割合と 流下漂流物群条件の関係を説明できていることがわか る.並木の津波漂流物捕捉機能評価おいて, 式 (1)，(2) による $R_{C 1}$ は，並木間隔や漂流物諸元に依存した幾何 学的条件によるものである，一方，式 (3)，(4)による $R_{C 2}$ は, 流下漂流物の密度や, 流勢 $\left(F_{r}\right)$ を考慮したも のであり，本研究では， $R_{C 1}, R_{C 2}$ は独立の関係にある と仮定する．以上から，漂流物密度や流勢を考慮した 漂流物捕捉機能評価は式 (5) で評価する .

$$
R_{\mathrm{c}}=R_{\mathrm{c} 1} \cdot R_{\mathrm{c} 2}
$$




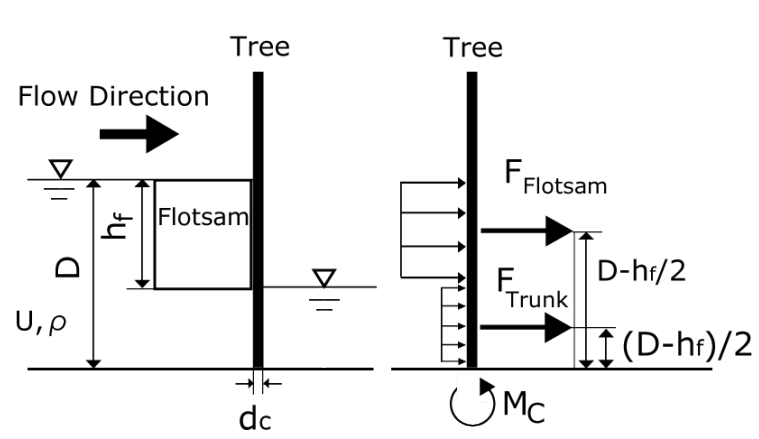

図-9 樹木にかかる倒伏モーメント $\left(D>h_{f}\right)$

3. 漂流物捕捉に伴う樹木の倒伏限界

\section{(1) 既存の樹木強度の評価}

以上の検討により，並木条件，漂流物条件と津波外 力から並木の津波漂流物捕捉機能について定量的な評 価を与えることが可能となった . しかしながら，漂流物 捕捉にともなった並木の倒伏は考慮していない，光こ で, 津波漂流物捕捉時の並木にかかる力について検討 を行い, 既往の樹木強度についての知見を用いて, 光 の限界について検討を行った .

並木を沿岸部の津波減災に活用する場合，津波に対 する樹木の倒伏耐力を検討する必要がある . 河道内樹 木の倒伏限界については, 既往の研究 ${ }^{13) 14)} に よ り$ 詳細 が調べられており，黑松に代表される沿岸部の樹木の 倒伏耐力については, 今井・鈴木 ${ }^{5)}$ が河道内樹木にお ける倒伏モーメント評価式に対する沿岸部の樹木への 適合性を確認している.以上の研究成果から樹木の倒 伏モーメントを樹木の胸高直径で定義することが可能 であり，樹木の倒伏モーメントを簡便かつ定量的に判 定可能である .しかしながら，樹木の群生環境が限定 的であることや評価值にばらつきがあることが課題と されている .

本稿では, 海岸林の林相調査及び黑松の引き倒し試 験結果を用いた今井ら ${ }^{15)}$ の倒伏評価モーメント式を用 いる.以下に式を示す。

$$
M_{C}=\beta \sigma_{b} W
$$

$\beta$ は群生環境係数であり, 樹木の胸高直径，樹木 占有率，根上部からの被砂層厚に依存する係数， $\sigma_{b}=28.3 \mathrm{~N} / \mathrm{mm}^{2}, \mathrm{~W}$ は幹直径 $d_{C}(\mathrm{~m})$ を用いた断面係数 $\left(=\pi d_{C}{ }^{3} / 32\right)$ である $\beta$ について, 本稿では試験結果の 平均値である $\beta=1.9$ と最小值である $\beta=1.2$ を用いて検 討を行った。

(2) 漂流物捕捉時の樹木にかかる倒伏モーメントの提案

津波漂流物を捕捉したときの樹木に作用する力を図9, 10 のように考える. 対象とする樹種は黑松で，並 木に捕捉された漂流物と漂流物によって排される流体 から受ける力を樹木 1 本あたりについて想定している . 本研究では並木に漂流物が水深方向に重なって捕捉さ

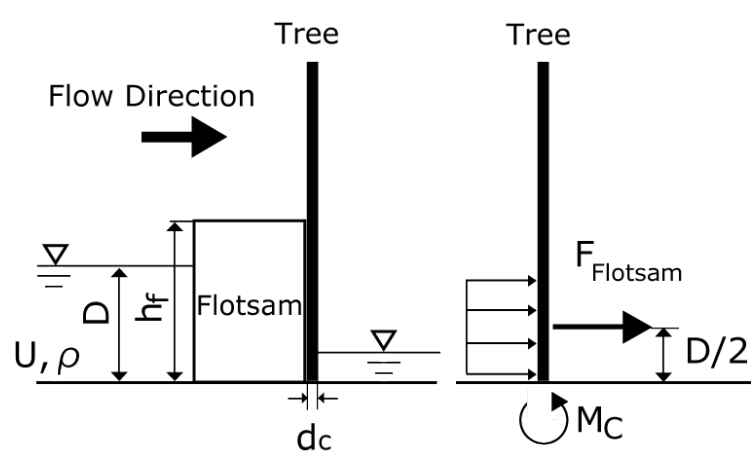

図-10 樹木にかかる倒伏モーメント $\left(D \leq h_{f}\right)$

れることは考慮せず, 漂流物の衝突力についても，本稿 では第 2〜3線の津波防災施設としての並木を想定した 検証であるために考慮せず，静的な荷重のみ検討した . 捕捉された漂流物群から並木全体に作用する力 $F_{\text {Flotsam }}$ を以下に示す .

$$
\begin{gathered}
F_{\text {Flotsam }}=\rho U^{2} \cdot R_{C} A_{\text {all }} \quad\left(D>h_{f}\right) \\
F_{\text {Flotsam }}=\rho U^{2} \cdot R_{C} A_{\text {all }} D / h_{f} \quad\left(D \leq h_{f}\right)
\end{gathered}
$$

$\rho$ は水の密度， $U$ は代表流速， $A_{\text {all }}$ は漂流物群の流向方 向投影面積， $h_{f}$ は漂流物高さである.漂流物の捕捉割合 は $A_{\text {all }}$ に反映すると仮定した . 漂流物の投影面積につい て, 設定した並木列に捕捉される漂流物の最大投影面積 $A_{\text {max }}$ を予め設定し,$A_{\text {max }} \leq R_{C} A_{\text {all }}$ の場合,$R_{C} A_{\text {all }}=A_{\text {max }}$ とすることで, 漂流物に捕捉される漂流物の量により 投影面積が無限に増大しないようにする .

樹幹部に作用する流体力 $F_{T r u n k}$ を以下に示す.

$$
F_{\text {Trunk }}=\frac{1}{2} \rho C_{D} U^{2} \cdot d_{C}\left(D-h_{f}\right)
$$

漂流物を捕捉したときの樹木の根部まわりのモーメ ントは式 (10)，(11)で表現される.

$$
\begin{gathered}
M_{C_{1}}=\frac{1}{2}\left(D-h_{f}\right) F_{\text {Trunk }}+\left(D-\frac{h_{f}}{2}\right) F_{\text {Flotsam }}^{\prime} \\
\left(D>h_{f}\right) \\
M_{C_{2}}=\frac{1}{2} D F_{\text {Flotsam }}^{\prime} \quad\left(D \leq h_{f}\right)
\end{gathered}
$$

ここで $F_{\text {Flotsam }}^{\prime}$ は樹木 1 本あたりにかかる $F_{\text {Flotsam }}$ で ある

\section{(3) 事例検証}

本稿では，東北地方太平洋沖地震津波にて確認され た，宮城県多賀城市栄 $2 丁$ 目における並木による津波 漂流物捕捉事例（図-1）について，本稿て提案した評価 手法をもとに検証を行った .

図-11 は宮城県多賀城市栄 $2 丁$ 目における並木による 津波漂流物捕捉事例にて確認された諸条件 (表-4) を もとに , 浸水深と漂流物捕捉を考慮した倒伏モーメン 卜の変化及び並木の津波漂流物捕捉割合の变化を示す． 図中の赤鎖線・黑鎖線(今井ら ${ }^{15)}$ による黑松の倒伏限 界モーメントの評価值を示し, 赤鎖線を上回ると樹木 の倒伏 ，下回れば樹木の残存を表す . 図から $F_{r}$ による 
表-4 検証事例諸条件

\begin{tabular}{|c|c|}
\hline 位置 & $\mathrm{N} 38.288^{\circ} \mathrm{E} 141.021^{\circ}$ \\
\hline \multirow{2}{*}{ 漂流物 } & 乗用車 $(5.0 \mathrm{~m} \times 2.0 \mathrm{~m} \times 1.5 \mathrm{~m})$ \\
\cline { 2 - 3 } & 幅 $50 \mathrm{~m}$ に 20 台 \\
\hline 流速 & $F_{r}=1.0,1.2,1.4$ の場合を検討 \\
\hline 並木間隔 & $3.6 \mathrm{~m}$ 間隔 1 列 \\
\hline 並木直径 & $0.37 \mathrm{~m}$ \\
\hline$R_{C}$ 条件 & $D_{f g}=0.5, F_{r}=1.2$ \\
\hline
\end{tabular}

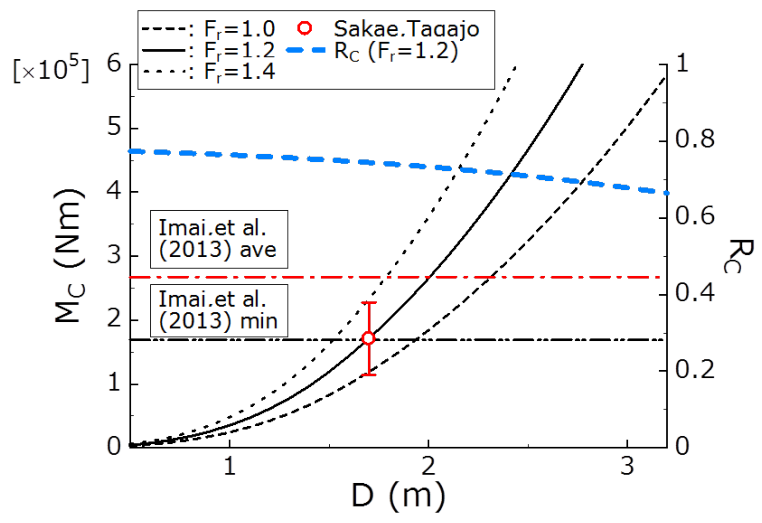

図-11 並木の倒伏モーメントの検証結果 (多賀城市)

ものの，漂流物の捕捉を考慮に入れた場合でも津波浸 水深が 1.8 2.3 m までなら，樹木は倒伏せず，漂流物 も多く捕捉を見込めることがわかる．光して，当該地 域における津波浸水深は現地調査結果及び国土地理院 の地形データから $1.7 \mathrm{~m}$ であり，当該地域の並木に倒伏 は確認されておらず，捕捉割合の值についても概ね現 地の状況と合致していることが確認できる .

\section{4. おわりに}

\section{本稿で得られた結果を以下に示す。}

1. 現地調査と水理実験から，並木の漂流物捕捉に関 わる物理因子を抽出し，並木の津波漂流物捕捉に ついて並木・漂流物群各諸元から光れらを定量的 に評価可能とする評価式を提案した .

2. 並木の津波漂流物捕捉機能に関する評価式を用い て, 津波漂流物捕捉時に樹木にかかる倒伏モ一メ ントの提案を行った .

3. 津波漂流物捕捉時の樹木にかかる倒伏モーメント の評価手法を用いて, 東北地方太平洋沖地震津波 における事例のもとで, 津波浸水深と並木にかか る倒伏モーメント，漂流物捕捉割合の関係を示し， 現地の状況について検証を行った .

謝辞: 東北大学工学部元助手の山路弘人氏，技術一般職 員の会田俊介氏には水理実験を遂行するにあたり，実 験水路の整備及び計測機器の調整・設置をしていただ くなど多大な助力を頂きました．また，本学修士学生 の橋本康平氏, 林里美氏, 久松明史氏, 堀内滋人氏, 北 海道ガス株式会社の堀川亮祐氏には水理実験を実施す
る際に多大な助力を頂きました . 図の作成には国土地 理院発行の「数值地図 25000 」を使用しました . 本研究 は科学研究補助金 (研究代表者: 今井健太郎, 若手研 究 (B): 課題番号 23710200), 平成 25-32 年度文部科学 省「南海卜ラフ広域地震防災研究プロジェクト」(研究 代表者: 独立行政法人海洋研究開発機構 プロジェクト リーダー 金田義行) の一環として行われました .ここ に記して，感謝の意を表します．

\section{参考文献}

1) 林野庁 (オンライン): http://www.rinya.maff.go.jp/j/tisan/tisan/pdf/dai5kai-siryou3.pdf，参照 5-21-2012

2) 首藤伸夫: 防潮林の津波に対する効果と限界，第 32 回海 岸工学講演会論文集, pp.465-469, 1985.

3) 原田賢治, 今村文彦: 防潮林による津波減衰効果の評価と 減災のための利用の可能性, 海岸工学論文集, 第 50 巻, pp.341-345, 2003.

4) 今井健太郎, 松冨英夫: 沿岸植生域を氾濫する津波の水理, 土木学会論文集 B, Vol.62, No.3, pp.258-269, 2006.

5) 今井健太郎, 鈴木明菜: 沿岸樹木のパイプモデルを用いた 表面積, 体積評価と炎の倒伏耐力, 水工学論文集, 第 49 巻, pp.306-310, 2005.

6) 今井健太郎，松冨英夫: 樹冠部の变形を考慮した樹木の抵 抗則と关れを用いた沿岸林域の氾濫計算, 土木学会論文 集 B, Vol.64，No.3，pp.214-225, 2008.

7) 柳澤英明, 越村俊一, 宮城豊彦, 今村文彦: 2004 年インド 洋大津波におけるマングローブ林のフラジリティー関数， 海岸工学論文集, 第 55 巻, pp.286-290, 2008.

8) 坂本知己，新山馨，中村克典，小谷英治，平井敬三，齋 藤武史, 木村公樹, 今純一: 東北地方太平洋沖地震津波 における海岸林の漂流物捕捉効果, 海岸林学会誌, 11(2), pp.65-71, 2012.

9) 今井健太郎, 林晃大, 今村文彦: 並木の津波漂流物捕捉機能 に関する基礎的検討，土木学会論文集 B2，Vol.69，No.2， p.1_401-1_405, 2012.

10）松冨英夫, 大沼康太郎, 今井健太郎: 植生域氾濫流の基 礎式と植生樹幹部の相似則, 海岸工学論文集, 第 51 巻, pp.301-305, 2004.

11) 木岡信治, 森昌也, 山本泰司, 遠藤強, 竹内貴弘: 流水 群とアイスブームの相互作用に関する水理模型実験と光 の数值計算に関する基礎的研究, 海洋開発論文集, 第 25 巻, pp.1053-1058, 2009.

12) Sugiura, N. : Further analysts of the data by akaike' s information criterion and the finite corrections, Communications in Statistics - Theory and Methods, 7(1), pp. 13-26, 1978.

13）渡邊康玄，市川嘉輝，井出康郎: 洪水時における河道内樹 木の倒伏限界, 水工学論文集，第 40 巻, pp.169-174, 1996.

14) リバーフロント整備センター 編集: 河川における樹木管 理の手引き, 山海堂 , pp.156-160, 1999.

15) 今井健太郎, 原田賢治, 南幸弘, 川口誠史, 二宮栄一: 海 岸樹木の津波耐力評価手法の高度化，土木学会論文集 B2， Vol.68, No.2 , p.1_361-1_365, 2013.

16) 国土地理院 (オンライン): 平成 23 年 (2011 年) 東北地方太平洋沖地震による被災地の空中写真, http://saigai.gsi.go.jp/h23taiheiyo-hr/index.html, 参 照 5-12-2012 